\title{
DARBAS NE VISĄ DARBO LAIKĄ LIETUVOJE IR KITOSE ES ŠALYSE: KITIMO TENDENCIJOS IR PAGRINDINĖS PROBLEMOS
}

\author{
Boguslavas Gruževskis, Rasa Zabarauskaitė \\ Lietuvos socialiniu tyrimu centras \\ Goštauto g. 11, LT-01108 Vilnius, Lietuva \\ doi:10.13165/VPA-13-12-4-02
}

Anotacija. Pastarajịdešimtmetịitin paspartèjusiospasaulio ekonomikos globalizavimo tendencijos bei informaciniu technologiju plètra turèjo didelès ìtakos darbo ištekliu panaudojimui ir darbo organizavimui dangelyje pasaulio šaliu. Siekiant subalansuoti gamybos poreikius ir darbo išteklius, jau devintame XX a. dešimtmetyje daugelyje šaliu aktyviai pradètos taikyti ịvairios lanksčios užimtumo formos. Bene labiausiai paplitusi iš ju yra darbas ne visq darbo laiką. Tačiau ši užimtumo forma skirtingose ES šalyse yra nevienodai paplitusi, tarp šaliu egzistuoja dideli skirtumai. Ǐ́ kitos pusès, darbas ne visa darbo laika, be pranašumu, turi ir tam tikru trūkumu. Straipsnyje siekiama objektyviai ivertinti pagrindinius darbo ne visa darbo laika pranašumus ir trūkumus bei kitimo tendencijas Lietuvoje ir kitose ES šalyse. Straipsnyje analizuojami darba ne visa darbo laika lemiantys veiksniai, nagrinejamas šios užimtumo formos reglamentavimas Lietuvoje ir paplitimo tendencijos kai kuriose ES šalyse.

Raktažodžiai: darbas ne visa darbo laika, lanksčios užimtumo formos, darbo laikas.

Keywords: part-time employment, flexible forms of employment, working time.

\section{Ivadas}

Šiuolaikiniam gyvenimui jau daugelị metų būdingas gyvenimo trukmès ilgėjimas ir kartu - darbo laiko trumpejjimas. Eurostato duomenimis, nuo XX a. pradžios iki $1980 \mathrm{~m}$. gyvenimo trukmè Vakarų Europos šalyse išaugo nuo 440 tūkst. iki 610 tūkst. valandų, o 2000 m. - padidèjo iki 700 tūkst. valandų. Priešingai kito darbo laikas daugelyje pasaulio šalių. Po Pirmojo ir ypač po Antrojo pasaulinio karo darbo laiko organizavimui buvo skiriama vis daugiau dèmesio. Itvedus 8 val. trukmès darbo laiką bei sutrumpinus darbo savaitę nuo 6 iki 5 dienų, darbo laikas vidutiniškai per žmogaus gyvenimą nuo XX a. pr. 
iki 1980 m. sutrumpejjo nuo 150 tūkst. iki 75 tūkst. val. ir trumpejja toliau. Šios tendencijos daugiausiai buvo paskatintos ekonominių, technologinių bei socialinių priežasčių [14].

Nuo XX a. pabaigos darbo laikas ir jo panaudojimas vis dažniau tampa ne tik ekonominių, tačiau ir vadybinių, psichologinių, socialinių ir net filosofinių tyrimų ir diskusijų objektu. Ekonomikos globalizavimas ir auganti konkurencija vis labiau skatina efektyviau išnaudoti darbo jègos išteklius, taupiau organizuoti darbo procesus ir mažinti darbo kaštus. Informacinès technologijos sudaro sąlygas lanksčiau organizuoti gamybą, sumažina gamybos proceso priklausomybę nuo masinès darbo jëgos poreikio ir supaprastina gamybinę komunikaciją erdvès ir laiko atžvilgiu. Iš kitos pusès, augantis gyvenimo lygis didina laisvo nuo darbo laiko vertę ir skatina trumpinti darbo laiką bei gerinti darbo ir ne darbo laiko balansą, siekiant užtikrinti darbuotojams didesnị pasitenkinimą darbo sferoje. Šiuos verslo ir dirbančiųjų poreikius atitinka darbas ne visą darbo laiką (angl-- part-time employment), t. y. darbas, kai darbo laikas nustatomas sumažinant savaitès darbo dienų skaičių, sutrumpinant darbo dieną (pamainą) ar derinant abu minètus variantus. Užimtumas ne visą darbo laiką šiuolaikinės ekonomikos sąlygomis sudaro galimybes suderinti individo darbo ir privataus gyvenimo poreikius. Tuo tarpu harmoningo darbo ir privataus gyvenimo laiko balanso užtikrinimas ne tik padidina gyvenimo kokybę, bet ir užtikrina efektyvesnį darbo išteklių panaudojimą. Atsižvelgiant ị tai minètiems klausimams tirti tikslinga skirti daugiau dèmesio ne tik mokslinès analizès, bet ir šalių socialinès, o ypač ekonominès politikos formavimo ir igyvendinimo lygmeniu. Taip pat tikslinga panagrinèti darbo ne visą darbo laiką sąsajas su skirtingais socialiniais ekonominiais rodikliais ES šalyse.

Tyrimo objektas - darbas ne visą darbo laiką ir jị lemiantys veiksniai.

Straipsnio tikslas - išanalizuoti pagrindinius darbo ne visą darbo laiką pranašumus ir trūkumus bei šią užimtumo formą skatinančius veiksnius, nustatyti darbo ne visą darbo laiką kitimo tendencijas Lietuvoje bei kitose ES šalyse. Straipsnyje analizuojami darbą ne visą darbo laiką lemiantys veiksniai, aptariamas darbo ne visą darbo laiką teisinis reglamentavimas Lietuvoje, nagrinèjamos šios užimtumo formos paplitimo tendencijos kai kuriose ES šalyse, ieškoma sąsajų tarp darbo ne visą darbo laiką rodiklio ir kitų socialinių ekonominių rodiklių Lietuvoje ir ES šalyse.

Straipsnyje taikomi tyrimo metodai: mokslinès literatūros analizè, palyginamoji analizè, kiekybiniai analizès metodai (koreliaciné analizè, statistinis duomenų aprašymas). Analizei naudojami Lietuvos Respublikos statistikos departamento bei Eurostato duomenys.

\section{Veiksniai, turintys įtakos darbo ne visą darbo dieną paplitimui}

$2011 \mathrm{~m}$. daugelyje ES šalių buvo nustatyta 40 val. darbo savaite (tikslinga išskirti Belgiją ir Prancūziją, kuriose nustatyta atitinkamai 37 val. ir 35 val. darbo savaitè). Eurostato duomenimis, $2011 \mathrm{~m}$. vidutinè darbo laiko trukmé ES šalyse sudare 37,4 val. per savaitę. Ilgiausiai buvo dirbama Graikijoje (beveik 42 val. per savaitę), Čekijoje, 
Bulgarijoje, Slovakijoje, Lenkijoje bei Rumunijoje. Trumpiausia vidutinė darbo laiko trukmè buvo Nyderlanduose (30,5 val. per savaitę), Danijoje, Airijoje bei Vokietijoje. Iš kitos pusès, reikia pažymèti, kad darbdaviai, norèdami patenkinti momentinius dèl rinkos ir gamybos plètros padidejjusius papildomų darbo išteklių poreikius, dažnai skatina darbuotojus dirbti viršvalandžius. Apie 50 proc. Europos darbo išteklių 2010-2011 m. dirbo tam tikrų formų viršvalandžius (po nustatytų darbo valandų, savaitgaliais, per šventes ar pan.) [17].

Vidutinio darbo laiko trukmès mažejimui didelę įtaką turi vis platesnis įvairių lanksčiu užimtumo formų taikymas, o labiausiai darbas ne visą darbo laiką. Kaip rodo tyrimai $[16,17]$, per pastaruosius kelis dešimtmečius Europoje darbo ne visą darbo laiką mastai vienodai didejjo tiek moterų, tiek vyrų. Vis dèlto moterys keturis kartus dažniau dirbo ne visą darbo laiką nei vyrai (procentinè dalis atitinkamai sudarė 32 proc. ir 8 proc.). Didesnè moterų, dirbančiu ne visą darbo laiką, dalis šalyje gali reikšti prieinamų vaikų priežiūros paslaugų trūkumą. Susiklosčiusių tradicijų darbo rinkoje skirtumai taip pat gali turèti nemažos įtakos darbo ne visą darbo laiką paplitimui šalyje [16]. Šiame kontekste darbo tradicijos suprantamos kaip istoriškai susiformavusių užimtumo formų bei su jomis susijusių vertybių perdavimas iš kartos ị kartą. Darbo tradicijos apima tokius svarbius su užimtumu susijusius aspektus kaip darbo užmokestis, teisinis darbo rinkos reguliavimas, darbo sąlygos, šeimos ir darbo ịsipareigojimų derinimas ir pan. Prie darbo tradicijų galima priskirti ir užimtumo smulkaus ir vidutinio sektoriaus įmonèse bei savarankiško užimtumo paplitimą (pvz., skirtumai tarp Šiaurès ir Pietų Europos šalių), socialinių partnerių bendradarbiavimo tradicijas bei darbuotojų gebejjimą atstovauti savo interesams (juos ginti) santykiuose su darbdaviais, profesinių sąjungų vaidmenị ir ịtaką darbo santykiams bei darbo apmokejimui ir pan.

Skirtingose ES šalyse pastebimi gana žymūs skirtumai, analizuojant darbuotojų, dirbančių ne visą darbo laiką, dalį. Šiuos skirtumus gali lemti skirtingi socialiniai ekonominiai veiksniai, tokie kaip [16,17]:

- darbo ne visą darbo laiką paklausos trūkumas;

- mažas vidutinis darbo užmokestis šalyje;

- teisinio reguliavimo trūkumas;

- žemo lygio ne viso darbo laiko darbo vietų kokybė;

- nedeklaruoto darbo ne visą darbo laiką paplitimas.

Kaip teigia Buddelmeyeris ir bendraautoriai [7], darbui ne visą darbo laiką didžiausios ịtakos turi šie veiksniai:

- verslo ciklai;

- darbo rinkos institucijos ir politika;

- kiti struktūriniai veiksniai.

Panagrinèsime šiuos veiksnius išsamiau.

Verslo ciklai lemia darbo ne visą darbo laiką lygio svyravimus trumpuoju ir vidutiniu laikotarpiais. Paklausos požiūriu galimos dvi ciklinių svyravimų poveikio darbui ne visą darbo laiką galimybès. Pirma, ekonominès krizès gali lemti persiskirstymą tarp atskirų sektorių, kadangi ekonomikos sektorius, kuriame didžioji dalis darbuotojų dirba visą dar- 
bo laiką (pvz., gamybos ar statybos sektorius), krizės paveikia anksčiau ir kur kas stipriau nei kitus sektorius. Atitinkamai, sektoriams, kuriuose vyrauja darbas ne visą darbo laiką, ekonomikos nuosmukiai gali neturèti tokios didelès neigiamos ịtakos. Antra, ekonominès krizès gali paskatinti spartų darbo ne visą darbo laiką apimties augimą, tokiu būdu sudarant galimybes darbdaviams prisitaikyti prie visuminès paklausos svyravimų [10]. Tokiu atveju esamiems darbuotojams sutrumpinamas darbo laikas arba tokios sąlygos taikomos naujai priimamiems darbuotojams. Taigi, darbo ne visą darbo laiką lygis gali mažiau koreliuoti su ekonominiais ciklais nei bendras užimtumo lygis. Netgi gali išryškèti priešingos tendencijos - darbo ne visą darbo laiką lygis gali padidèti, nepaisant bendro užimtumo lygio mažejimo. Tokios tendencijos praktikoje išryškèjo ES šalyse po $2008 \mathrm{~m}$. krizès, kai daugelyje šaliu buvo pradètos taikyti įvairios užimtumo išsaugojimo schemos, kurių pagrindą sudare darbo laiko trumpinimas [17]. Iš kitos pusès, darbas ne visą darbo laiką gali būti susijęs ir su kitais veiksniais. Pavyzdžiui, neretai darbdaviai, pasiūlydami darbuotojui darbą ne visą darbo laiką, siekia išbandyti jo tinkamumą darbui. Tokiu atveju po tam tikro laiko darbuotojui pasiūloma dirbti visą darbo laiką [7].

Verslo ciklai turi trumpalaikès ar vidutinio ilgumo įtakos darbo ne visą darbo laiką mastams, o darbo rinkos ir instituciniai veiksniai turi didesnès įtakos ilgalaikejje perspektyvoje. Mokslinès literatūros šaltinių analizè parodè, kad darbo ne visą darbo laiką paplitimui šalyje didžiausios ịtakos turi šie darbo rinkos instituciniai veiksniai $[4,7,10,17]$ :

- Darbo ne visą darbo laiką reglamentavimas (numatytas įstatymais ar grindžiamas kolektyviniais susitarimais) turi didelès ịtakos darbui ne visą darbo laiką. Pastarasis veiksnys gali turèti ịtakos ne visos darbo dienos užimtumui trimis pagrindiniais būdais. Pirma, teisès aktai gali turèti tiesioginès įtakos darbui ne visą darbo laiką, kai yra taikomi tam tikri apribojimai minètai užimtumo formai plètoti. Antra, užimtumas ne visą darbo laiką gali būti veikiamas per teisès aktus, reglamentuojančius darbuotojų darbo užmokestí, socialinę apsaugą ar mokesčiu bei pašalpų sistemą. Kai kuriose šalyse (pvz., Portugalijoje) teisiškai reglamentuotas vienodas tiek darbo visą, tiek ir ne visą darbo laiką valandinio darbo užmokesčio dydis. Tai gali sumažinti darbdavių motyvaciją kurti ne viso darbo laiko vietas. Kitose šalyse įmonėms, įdarbinančioms asmenis darbui ne visą darbo laiką, gali būti taikomos mokestinès nuolaidos arba subsidijos, tai atitinkamai skatina darbdavius kurti daugiau tokių darbo vietų. Trečia, darbą ne visą darbo laiką gali paskatinti atitinkamų teisès aktų, skatinančių šeimos ir karjeros derinimą, prièmimas šalyje.

- Skirtingų socialinių išmokų mokejjimo tvarka taip pat turi nemažos įtakos darbo ne visą darbo laiką paplitimui šalyje. Pvz., esant didelèms nedarbo socialinio draudimo išmokoms, gali būti sukuriami „nedarbo spąstai“, neskatinantys dirbti ne visą darbo laiką, kadangi neretai asmenų, dirbančių ne visą darbo laiką, darbo užmokestis yra mažesnis nei dirbančiųjų visą darbo laiką. Panaši situacija gali susiklostyti ir kitais atvejais, kai šalies gyventojams teikiama pajamomis testuojama socialinè parama.

- Mokesčių sistema taip pat gali turèti įtakos darbo ne visą darbo laiką mastui šalyje. Didelis pagal pajamų lygị nediferencijuotas pajamų mokestis gali sumažinti paskatas dirbti ne visą darbo laiką, kadangi didelè pajamų dalis atiteks mokesčiams. 
- Mažas vidutinis darbo užmokestis (VDU) šalyje. Iš 2009 m. Eurofoundo užsakymu atliktos Europos įmonių apklausos dèl darbo ne visą darbo laiką Europoje matyti, kad daugelyje ES šalių darbuotojai, dirbantys ne visą darbo laiką, vidutiniškai gauna mažesni darbo užmokestị bei turi mažesnes galimybes siekti karjeros. Pvz., gerai savo karjeros galimybes vertino 35 proc. darbuotojų, dirbančių 40 val. ir daugiau, tačiau dirbančių 20 val. ir mažiau taip vertinančių dalis sudare tik 23 proc. Taip pat reikia pažymėti, jog sutrumpintą darbo laiką dirbančios moterys vidutiniškai blogiau vertino savo karjeros galimybes nei vyrai [17].

Tyrimai rodo, kad darbo ne visą darbo laiką mastams nemažos įtakos turi ir kiti struktūriniai veiksniai, tokie kaip moterų dalyvavimas darbo rinkoje, 15-24 metų amžiaus gyventojų skaičius, gimstamumo lygis ir kt. Buddelmeyeris ir bendraautoriai [7] nustatė, kad egzistuoja stipri teigiama koreliacija tarp gimstamumo lygio ir užimtumo ne visą darbo laiką lygio. Tai rodo, kad darbas ne visą darbo laiką iš tiesų sudaro galimybes moterims suderinti vaikų priežiūrą su darbo ịsipareigojimais. Tyrimai taip pat rodo, kad neretai dirbti ne visą darbo laiką renkasi ir jaunimas (tiek vyrai, tiek moterys), tokiu būdu siekdami užsidirbti papildomų pajamų studijų metu. Pabaigę studijas, vis dèlto daugelis jų renkasi darbą visą darbo laiką. Vyresnio amžiaus asmenys taip pat gali rinktis darbą ne visą darbo laiką dèl sveikatos problemų ar siekdami laipsniško išèjimo ị pensiją.

Europos fondas gyvenimo ir darbo sąlygoms gerinti (2011) išskiria šiuos užimtumui ne visą darbo laiką įtakos turinčius veiksnius [16]:

- Kokybiškų vaiko priežiūros paslaugų prieinamumas. Tyrimai rodo, kad tinkamos kokybės ir už prieinamą kainą teikiamos vaikų priežiūros paslaugos skatina tẻvus dirbti visą darbo dieną. Tuo tarpu, esant brangioms vaikų priežiūros paslaugoms, vienas iš tėvų paprastai turi sumažinti dirbamų valandų skaičių, kad galètų pasirūpinti vaiku (-ais).

- Darbo valandų kultūrų skirtumai. Skirtingų šalių visuomenès turi skirtingus požiūrius ị darbo laiką. $2008 \mathrm{~m}$. darbo jëgos tyrimų duomenimis, visą darbo laiką dirbančio darbuotojo vidutinis darbo valandų skaičius per savaitę svyruoja nuo 39 iki 44 val. Vienose šalyse (pvz., Jungtinëje Karalysteje ar naujosiose ES šalyse narèse) yra priimtina dirbti ilgas darbo valandas, tuo tarpu kitose (Prancūzijoje, Švedijoje, Olandijoje ir kt.) ịprastas darbo laikas yra trumpesnis nei vidutiniškai ES.

- Žemo lygio ne viso darbo laiko darbo vietų kokybė. Atlikti tyrimai rodo, kad daugelyje darbo rinkų yra sukuriama mažiau aukštesnès kokybės laisvų darbo vietų darbui ne visą darbo laiką lyginant su darbu, kai dirbama visą darbo laiką.

- Teisinio reglamentavimo skirtumai. Skirtingose šalyse sukurti skirtingi teisiniai pagrindai, reglamentuojantys darbo ne visą darbo laiką politiką. Kai kurios įmonės sutrumpina darbuotojų darbo laiką, kad patenkintų savo poreikius (t. y. prisitaikytų prie sumažèjusios visuminès paklausos), kitos - siekdamos prisitaikyti prie darbuotojų poreikių. Dar kitos įmonès ne viso darbo laiko režimą taiko dẻl abiejų minètų priežasčių.

Taip pat reikia pažymèti, jog darbas sutrumpintą darbo laiką dažnai priklauso ir nuo asmens lygmens priežasčių: amžiaus, sveikatos būklès, lyties, išsilavinimo, šeiminès padèties, îsipareigojimų šeimoje ir pan. 


\section{Darbo ne visą darbo laiką pranašumai ir trūkumai}

Remiantis mokslinès literatūros šaltinių analize, darbas ne visą darbo laiką turi teigiamos įtakos tiek šalies gyventojų gyvenimo kokybei, tiek ir visai šalies ekonomikai. Užimtumas ne visą darbo laiką suteikia darbuotojams daugiau lankstumo, leidžia planuoti ir paskirstyti darbo jẻgos paklausą, atsižvelgiant i gamybos reikalavimus. Taip pat lankstūs darbo organizavimo modeliai sudaro galimybes darbuotojams geriau kontroliuoti laiką, derinti šeimos ịsipareigojimus ir karjerą, mažina stresą darbe, didina pasitenkinimą darbu $[5,8]$.

\section{1 lentele. Teigiami ir neigiami darbo ne visą darbo laiką aspektai}

\begin{tabular}{|c|c|c|c|}
\hline & Darbdaviui & Darbuotojui & Valstybei \\
\hline $\begin{array}{l}\text { Teigiami } \\
\text { aspektai }\end{array}$ & $\begin{array}{l}\text { - sudaro galimybes } \\
\text { darbdaviams pakoreguoti } \\
\text { darbo valandas ir taip } \\
\text { prisitaikyti prie verslo } \\
\text { ciklo sąlygų } \\
\text { - produkcijos ir darbo } \\
\text { kaštų reguliavimas } \\
\text { (pritaikymas) sudaro } \\
\text { galimybes išsaugoti } \\
\text { veiklos produktyvumą } \\
\text { - sudaro galimybes } \\
\text { atsižvelgti ị darbuotojų } \\
\text { poreikius }\end{array}$ & $\begin{array}{l}\text { - sudaro galimybes geriau } \\
\text { suderinti darbo ir šeimos } \\
\text { isipareigojimus } \\
\text { - palengvina laipsnišką } \\
\text { iejjimą i darbo rinką } \\
\text { ar išejimą iš jos viso } \\
\text { gyvenimo ciklo metu } \\
\text { - gali padidinti } \\
\text { pasitenkinimą darbu ir } \\
\text { gyvenimu }\end{array}$ & $\begin{array}{l}\text { - didina šalies gyventojų } \\
\text { dalyvavimą darbo } \\
\text { rinkoje (ypač moterų) }\end{array}$ \\
\hline $\begin{array}{l}\text { Neigiami } \\
\text { aspektai }\end{array}$ & $\begin{array}{l}\text { - dèl fiksuotų kaštų } \\
\text { (samdymo, mokymo ir } \\
\text { pan.) darbas ne visą darbo } \\
\text { dieną gali lemti didesnius } \\
\text { darbo kaštus }\end{array}$ & $\begin{array}{l}\text { - darbo užmokestis } \\
\text { paprastai yra žemesnis } \\
\text { nei dirbančiųuų visą darbo } \\
\text { laiką } \\
\text { - mažesnės išmokos } \\
\text { - mažesnės karjeros } \\
\text { galimybės } \\
\text { - perèjimas nuo darbo visą } \\
\text { darbo laiką prie darbo ne } \\
\text { visą darbo laiką gali būti } \\
\text { sudètingas } \\
\text { - gali mažinti } \\
\text { pasitenkinimą darbu } \\
\text { - prastesnè darbo vietos } \\
\text { kokybe் }\end{array}$ & $\begin{array}{l}\text { - neefektyvus išteklių bei } \\
\text { investicijų į žmogiškąji } \\
\text { kapitalą panaudojimas } \\
\text { (turint omenyje, kad } \\
\text { darbuotojų, dirbančių } \\
\text { ne visą darbo laiką, } \\
\text { išsilavinimo lygis } \\
\text { paprastai aukštas ) }\end{array}$ \\
\hline
\end{tabular}

Šaltinis: [16] 
Vis dèlto darbas ne visą darbo dieną gali turèti ir neigiamos ịtakos darbuotojams. Nemažai studijų parodè, kad dirbantieji ne visą darbo laiką dažniau dirba paprastesnị ir mažiau mokamą darbą lyginant su visą darbo laiką dirbančiais darbuotojais [16,17]. Atlikus tyrimą Jungtinėje Karalysteje nustatyta, kad apytiksliai pusès (51 proc.) ne visą darbo laiką dirbančių vyrų ir moterų nuomone, darbo metu jie neišnaudoja viso savo potencialo. Be to, dirbantieji ne visą darbo laiką rečiau dalyvauja mokymuose ir tobulinimo kursuose, jiems sudaromos mažesnès karjeros galimybès lyginant su visą darbo laiką dirbančiais darbuotojais. Tyrimai rodo, kad netgi darbuotojai, dirbantys pagal terminuotas darbo sutartis, turi didesnes galimybes būti paaukštinti darbe tuo atveju, jeigu dirba visą darbo laiką. Tiesa, šis teiginys dažniau pasitvirtina kalbant apie moteris nei apie vyrus [16]. Detaliau teigiami ir neigiami darbo ne visą darbo laiką aspektai nagrinëjami 1 lentelèje.

Taip pat reikia pažymėti, kad senųų ES šalių narių mokslininkų darbuose nepakankamai atskleista žemo VDU šalyje įtaka darbo ne visą darbo laiką paplitimui. ES-15 vidutiniškai minimali mėnesinė alga yra apie 2-3 kartus didesnè nei realus minimalus gyvenimo lygis. Atitinkamai didesnès yra ir šeimų (4 asmenų) disponuojamos pajamos. Pvz., 2011 m. Lietuvoje jos sudarè 18,4 tūkst. eurų, o Airijoje 41 tūkst., Italijoje beveik 49 tūkst., o D. Britanijoje 56,5 tūkst. Kiek mažesnès disponuojamos pajamos buvo Portugalijoje bei Graikijoje (sudarè apytiksliai 33 tūkst. eurų keturių asmenų šeimai).

Dèl minètų ir kitų priežasčių mažesnio darbo užmokesčio šalyse darbas ne visą darbo laiką nèra itin patrauklus darbuotojams. Pvz., 2008 m. Šiaulių apskrityje atlikta gyventojų apklausa parodè, kad darbas ne visą darbo laiką yra vertinamas kaip patraukli darbo organizavimo forma, tačiau ji daugiau priimtina darbo neturintiems nei dirbantiems asmenims [18]. Panašiai galima traktuoti ir Europos fondo atlikto ES šalių darbo ne visą darbo laiką tyrimo rezultatus, kurie parodè, kad, nors nuolat auga vyrų, dirbančių ne visą darbo laiką, dalis, tačiau vyrai sutrumpintą darbo laiką dažniausiai dirba tik karjeros pradžioje iki 30-35 metų amžiaus [17].

Vertindami darbo ne visą darbo laiką perspektyvas, turime analizuoti 3 pagrindines problemas:

- darbo išteklių panaudojimo atitikties ūkio poreikiams;

- gyventojų socialinio (pajamų) saugumo užtikrinimo didejjančio užimtumo lankstumo sąlygomis;

- darbo ir privataus gyvenimo balanso užtikrinimo.

Nepakankamai efektyviai panaudojant darbo išteklius bei darbo laiką, auga gamybos kaštai, mažèja ịmonès (šalies) konkurencingumas bei investicinis patrauklumas. Iš kitos pusès, didejjantis užimtumo lankstumas, kai pajamos mažesnès, gali neigiamai veikti gyventojų socialinị saugumą bei jų gyvenimo lygị, kas ilgalaikèje perspektyvoje turès neigiamą įtaką ekonomikai, nes mažins darbo motyvaciją, norą tobulinti žmogiškąji kapitalą, vartotojišką šios darbuotojų grupès paklausą ir didins personalo kaitą.

Nuo XX a. pabaigos vis labiau neigiamą įtaką darbo išteklių panaudojimui turi netinkamas darbo ir privataus gyvenimo balansas. Neigiamos pasekmès pasireiškia ir socialinejje, ir ekonomikos srityse. Tyrimų duomenimis, netinkamas balansas lemia didesnị darbuotojų stresą, itampą šeimos gyvenime. Dèl to didèja susirgimų, skyrybų, kas atitinkamai atsiliepia darbo našumui, norui pakeisti darbą ir pan. [6,8]. 
Taigi, apibendrinant galima teigti, kad darbas ne visą darbo laiką yra efektyvi priemonè, leidžianti pasiekti darbo ir privataus gyvenimo balansą, tačiau su sąlyga, kad jis užtikrins pakankamas pajamas ir neblogins kitų individo profesinės veiklos sąlygų: kvalifikacijos këlimo, karjeros galimybių ir kt.

\section{Darbo ne visą darbo laiką reglamentavimas Lietuvoje}

Darbą ne visą darbo laiką Lietuvoje reglamentuoja Darbo kodekso (DK) 146 straipsnis (Žin., 2002, Nr. 6-228). Remiantis 2003 m. sausio 1 d. Lietuvoje ịsigaliojusio DK minètu straipsniu, ne visas darbo dienos arba darbo savaitės darbo laikas Lietuvoje yra nustatomas: 1) darbuotojo ir darbdavio susitarimu; 2) darbuotojo reikalavimu dèl jo sveikatos būklès pagal sveikatos įstaigos išvadą; 3) pareikalavus néščiai moteriai, neseniai pagimdžiusiai moteriai, krūtimi maitinančiai moteriai, darbuotojui, auginančiam vaiką iki trejų metų, bei darbuotojui, vienam auginančiam vaiką iki keturiolikos metų arba neigalų vaiką iki aštuoniolikos metų; 4) darbuotojo iki aštuoniolikos metų reikalavimu; 5) neigaliojo reikalavimu pagal Neigalumo ir darbingumo nustatymo tarnybos prie Socialinės apsaugos ir darbo ministerijos išduotą išvadą; 6) darbuotojo, slaugančio sergantị šeimos narị, reikalavimu pagal sveikatos įstaigos išvadą. Svarbu pažymèti tai, kad darbdaviui teisès aktais nèra sudaryta galimybė vienašališkai sutrumpinti dienos ar savaitės darbo laiką, tuo tarpu darbuotojui atskirais atvejais tokia teisé yra sudaroma.

Remiantis DK, jeigu kitaip nenustatyta sveikatos priežiūros įstaigos išvadoje, susitarus ne visas darbo laikas gali būti nustatomas sumažinant savaitės darbo dienų skaičių arba sutrumpinant darbo dieną (pamainą), arba darant ir viena, ir kita. Ne viso darbo laiko darbo diena gali būti suskaidoma dalimis. Kitas su ne viso darbo laiko nustatymo tvarka susijusias sąlygas nustato šalies Vyriausybė. Vyriausybès nustatytos sąlygos gali būti netaikomos, kai dèl to susitariama kolektyvineje sutartyje. Remiantis DK, darbas ne viso darbo laiko sąlygomis dirbantiems darbuotojams nesukelia jokių apribojimų nustatant kasmetinių atostogų trukmę, apskaičiuojant darbo stažą, skiriant ị aukštesnes pareigas, keliant kvalifikaciją, neapriboja kitų darbuotojo darbo teisių, palyginti su darbuotojais, kurie dirba tokị patị ar lygiavertị darbą viso darbo laiko sąlygomis, atsižvelgiant ị darbo stažą, kvalifikaciją ir kitas aplinkybes. Darbas apmokamas proporcingai dirbtam laikui arba atliktam darbui.

Taip pat verta pažymėti, kad $2007 \mathrm{~m}$. darbo ne visą darbo laiką reglamentavimas buvo liberalizuotas, panaikinant nuostatas, kad sutrumpinta darbo diena neturi būti trumpesné nei puse ịstatymais numatytos darbo dienos, o sutrumpinta darbo savaite - ne trumpesné nei trys darbo dienos (Žin., 2007, Nr. 128-5219).

Darbui ne visą darbo laiką Lietuvoje taikoma Europos Bendrijos (EB) darbo ne visą darbo dieną direktyva (97/81/EB), kurios tikslas - sumažinti ne visą darbo dieną dirbančiu darbuotojų diskriminaciją, gerinti darbo ne visą darbo dieną kokybę, sudaryti sąlygas savanoriškai dirbti ne visą darbo dieną ir padèti lanksčiai organizuoti darbo laiką, atsižvelgiant ị darbdavių bei darbuotojų poreikius. Minèta direktyva buvo perkelta ị Lietuvos 
teisès aktus $2002 \mathrm{~m}$. birželio 24 d. prièmus naują Darbo kodeksą, jis įsigaliojo nuo $2003 \mathrm{~m}$. sausio $1 \mathrm{~d}$., bei jo papildymo ir pakeitimo ịstatymus. Taip pat igyvendinant darbo laiko politiką Lietuvoje yra svarbios ir kitos EB direktyvos - tai EB darbo laiko direktyva (93/104/ EB), nustatanti darbo valandų taisykles, bei EB vienodo vyrų ir moterų darbo užmokesčio direktyva (75/117/EEB), draudžianti bet kokios rūšies darbuotojų diskriminaciją dèl lyties.

\section{Darbo ne visą darbo laiką paplitimas Lietuvoje ir kitose ES šalyse}

Kaip rodo Eurostato duomenys, dirbantieji ne visą darbo laiką Lietuvoje sudaro nedidelę visų dirbančiųjų dalị. $2012 \mathrm{~m}$. Lietuvoje ne visą darbo laiką dirbo 110 tūkst. šalies gyventojų arba 8,8 proc. visų darbuotojų (žr. 2 ir 3 lenteles). Darbuotojų, dirbančių visą ir ne visą darbo laiką, skaičius itin sumažèjo $2008 \mathrm{~m}$. prasidejus ekonomikos nuosmukiui šalyje. Tokią situaciją galèjo lemti tai, kad darbuotojai, dirbantys ne visą darbo dieną, galëjo būti atleisti pirmiausia. Per 2000-2012 m. laikotarpị ne visą darbo laiką dirbančiu darbuotojų skaičius Lietuvoje sumažèjo nuo 123,5 tūkst. iki 110 tūkst. asmenų. Verta pažymėti ir tai, kad dirbančiųjų ne visą darbo laiką dalis Lietuvoje dar labiau sumažètų, jeigu pateikiant statistiką nebūtų ịskaičiuojami asmenys, dirbantys ne visą darbo laiką ne pagrindinèje darbovieteje.

2 lentele. Darbuotojų, dirbančių visą ir ne visą darbo laiką, skaičiaus dinamika 2000-2012 m. Lietuvoje (15-64 metų amžiaus grupẻje) (tūkst.)

\begin{tabular}{|l|c|c|c|c|c|c|c|c|c|c|c|c|c|}
\hline & 2000 & 2001 & 2002 & 2003 & 2004 & 2005 & 2006 & 2007 & 2008 & 2009 & 2010 & 2011 & 2012 \\
\hline $\begin{array}{l}\text { Dirbantieji } \\
\text { ne visą darbo } \\
\text { laiką }\end{array}$ & 123,5 & 112,8 & 133,1 & 123,7 & 118,9 & 99,2 & 140 & 122,2 & 96,4 & 110,5 & 101,3 & 101,9 & 110,0 \\
\hline $\begin{array}{l}\text { Dirbantieji } \\
\text { visą darbo } \\
\text { laiką }\end{array}$ & 1258,2 & 1230,3 & 1262,3 & 1318,9 & 1297,3 & 1354,7 & 1336 & 1383,6 & 1393,8 & 1277,1 & 1218,3 & 1126,1 & 1137,1 \\
\hline
\end{tabular}

Šaltinis: Eurostat

Kaip jau minèta, 2003 m. LR DK buvo ịtvirtintos EB direktyvos 97/81/EB, reglamentuojančios darbą ne visą darbo laiką, nuostatos Lietuvoje. Nors nebuvo atlikta specialių tyrimų, nagrinëjančių šios direktyvos ịtaką darbo ne visą darbo laiką paplitimo tendencijoms šalyje, galima teigti, kad direktyvos nuostatų įtvirtinimas neturejo žymios įtakos darbuotojų, dirbančių ne visą darbo laiką, skaičiui Lietuvoje.

Kaip rodo Eurostato duomenys, kiek dažniau Lietuvoje ne visą darbo laiką dirba moterys nei vyrai - $2012 \mathrm{~m}$. jų dalis šalyje atitinkamai sudare 10,6 proc. ir 6,9 proc. (žr. 1 pav.). İdomu, kad 2012 m. vyrų, dirbančių ne visą darbo laiką, dalis Lietuvoje buvo tik nežymiai mažesnè už EU-27 vidurkị (8,4 proc.), tuo tarpu moterų - apytiksliai 3 kartus mažesnè nei EU-27 vidurkis (32,1 proc.). 


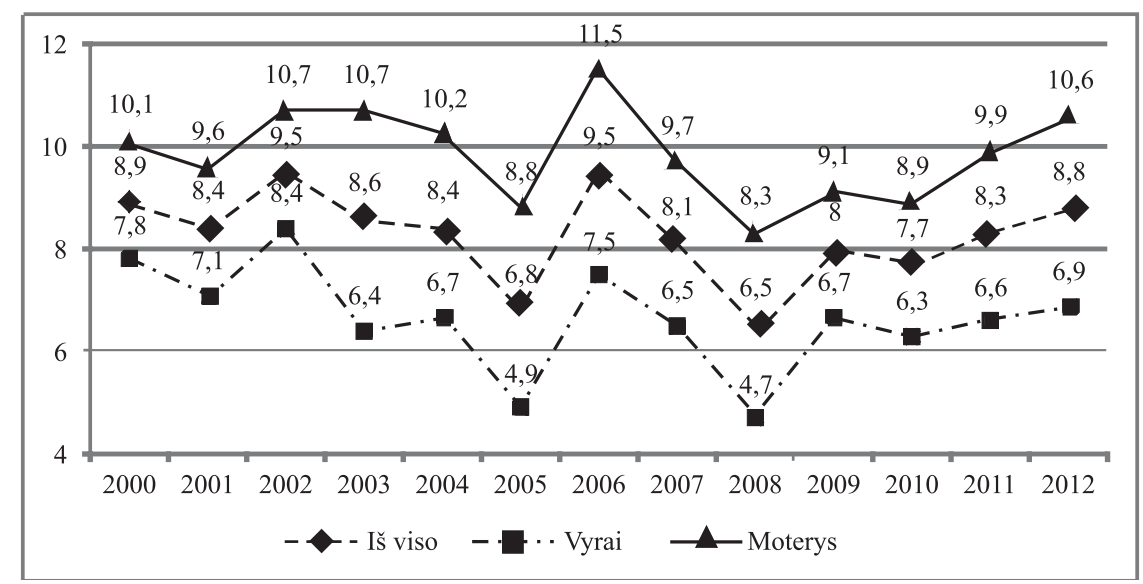

1 pav. Dirbančiųjų ne visą darbo laiką dalis nuo bendro užimtųjų skaičiaus Lietuvoje 2000-2012 metais (15-64 metų amžiaus grupẻje) (\%)

Šltinis: Eurostat

Nagrinėjant ne visą darbo laiką dirbančių asmenų pasiskirstymą pagal amžiaus grupes matyti, kad didžiąją dalị visų pagal minètą užimtumo formą dirbančių asmenų sudarè 25-49 metų amžiaus asmenys (60,4 proc.). 15-24 metų amžiaus ir 50-64 metų amžiaus asmenys atitinkamai sudare 12,5 proc. ir 35,8 proc. Taigi, kaip matyti, Lietuvoje nei jaunimas, nei vyresnio amžiaus asmenys nėra pagrindinès grupès, besinaudojančios ne viso darbo laiko užimtumo forma.

3 lentele. Dirbančiųjų ne visą darbo laiką dalis nuo bendro užimtųjų skaičiaus kai kuriose ES šalyse 2003-2012 metais (15-64 metų amžiaus grupèje) (\%)

\begin{tabular}{|l|c|c|c|c|c|c|c|c|c|c|}
\hline & 2003 & 2004 & 2005 & 2006 & 2007 & 2008 & 2009 & 2010 & 2011 & 2012 \\
\hline ES-27 & 16,1 & 16,7 & 17,3 & 17,5 & 17,6 & 17,6 & 18,1 & 18,6 & 18,8 & 19,2 \\
\hline Nyderlandai & 44,6 & 45,2 & 45,7 & 45,8 & 46,3 & 46,8 & 47,7 & 48,3 & 48,5 & 49,2 \\
\hline $\begin{array}{l}\text { Jungtine } \\
\text { Karalyste }\end{array}$ & 25,0 & 25,1 & 24,2 & 24,3 & 24,2 & 24,2 & 25,0 & 25,7 & 25,5 & 25,9 \\
\hline Bulgarija & 2,1 & 2,7 & 1,9 & 1,8 & 1,5 & 2,0 & 2,1 & 2,2 & 2,2 & 2,2 \\
\hline Slovakija & 2,2 & 2,5 & 2,4 & 2,7 & 2,5 & 2,5 & 3,4 & 3,8 & 3,9 & 4,0 \\
\hline Latvija & 9,4 & 9,8 & 7,6 & 5,8 & 5,6 & 5,5 & 8,4 & 9,3 & 8,8 & 8,9 \\
\hline Estija & 6,7 & 6,9 & 6,6 & 6,7 & 7,2 & 6,4 & 9,4 & 9,8 & 9,3 & 9,2 \\
\hline Lenkija & 9,3 & 9,6 & 9,8 & 8,9 & 8,5 & 7,7 & 7,7 & 7,6 & 7,3 & 7,2 \\
\hline Lietuva & 8,6 & 8,4 & 6,8 & 9,5 & 8,1 & 6,5 & 8,0 & 7,7 & 8,3 & 8,8 \\
\hline
\end{tabular}


Nagrinejjant Lietuvos situaciją ES šalių kontekste matyti, kad Lietuva patenka tarp šalių, kuriose darbas ne visą darbo laiką nėra plačiai paplitęs. $2012 \mathrm{~m}$. mažiausia dirbančiųjų ne visą darbo laiką dalis lyginant su bendruoju užimtųjų skaičiumi buvo Bulgarijoje ir Slovakijoje (atitinkamai sudare 2,2 proc. ir 4,0 proc.), didžiausia - Nyderlanduose ir Jungtinèje Karalystėje (49,2 proc. ir 25,9 proc.) (žr. 3 lentelę). Baltijos šalyse bei Lenkijoje dirbančiųjų ne visą darbo laiką dalis buvo panaši ir nagrinèjamuoju laikotarpiu svyravo apie 7-9 proc. 2012 m. ES-27 dirbančiųjų ne visą darbo laiką rodiklis sudarė 19,2 proc.

Žemą darbo ne visą darbo laiką lygị Lietuvoje ir kitose postkomunistinèse šalyse daugiausiai lėmé žemas vidutinis darbo užmokestis šalyje bei šiose šalyse susiklosčiusios darbo tradicijos, kai, vyraujant planinei ekonomikai, visi sprendimai buvo priimami centralizuotai ir nebuvo daug vietos lankstumui nacionaliniuose darbo santykiuose. Be to, vienas iš pagrindinių buvusios užimtumo politikos ir visos visuomenès tikslų buvo visiškas užimtumas. Tai turejo įtakos didesniam darbuotojų, dirbančiu visą darbo laiką, skaičiui minètose šalyse [1]. Lietuvos statistikos departamento (LSD) duomenimis, 2012 $\mathrm{m}$. IV ketv. ne visą darbo laiką dirbusių darbuotojų vidutinis mėnesinis bruto darbo užmokestis Lietuvoje sudare 797,4 Lt ir buvo beveik 3 kartus mažesnis nei visą darbo laiką dirbusių darbuotojų vidutinis mėnesinis bruto darbo užmokestis $(2232,0 \mathrm{Lt})$. Sutrumpinto darbo laiko nepatrauklumą Lietuvoje, Latvijoje, Estijoje ir Airijoje rodo ir tai, jog apie 20 proc. dirbančiųjų ne visą darbo laiką šiose šalyse pažymèjo, jog pageidautų dirbti ilgesnị darbo laiką [17].

Iš dalies mažą ne visą darbo laiką dirbančių asmenų skaičių Lietuvoje lemia ir tai, kad darbdaviai nėra itin suinteresuoti priimti darbuotojus ne visam darbo laikui dèl nepakankamų žinių, susijusių su ne viso darbo laiko užimtumo organizavimu ir valdymu. Dažnai darbdaviui neapsimoka samdyti kelis darbuotojus, dirbančius ne visą darbo laiką, jiems įrengti darbo vietas, sudaryti darbo grafikus ir pan. Kur kas paprasčiau yra ịdarbinti vieną darbuotoją [3]. Iš kitos pusès, neretai darbu ne visą darbo laiką darbdaviai pasinaudoja kaip darbo kaštų mažinimo priemone. Valstybinès darbo inspekcijos duomenimis, vieni dažniausių darbo įstatymų Lietuvoje pažeidimų - yra darbo laiko apskaitos pažeidimai. Neretai tai susiję ne tik su viršvalandinio darbo apskaitos vengimu, bet ir paslëptomis valandomis, kai žymima, kad darbuotojai dirba mažiau valandų (sutariama dèl ne viso darbo laiko), tačiau praktiškai darbo diena ar savaitė yra ilgesnè ir neretai trunka net ilgiau nei leidžia ịstatymai. Darbuotojai nesiskundžia dèl tokių darbo laiko pažeidimų, nes dèl didelio nedarbo neturi alternatyvių darbo pasiūlymų, gauna dalị darbo užmokesčio „vokelyje“ ir išsaugo teisę i i piniginę socialinę paramą bei savivaldybès mokamas šildymo ir kitas kompensacijas. Tokia praktika plačiau paplitusi statybos ir mažmeninės prekybos sektoriuose $[1,2,3,12]$.

Tokias tendencijas patvirtina ir statistiniai duomenys, rodantys, kad gana didele dalis darbuotojų Lietuvoje ne visą darbo laiką dirba ne savo noru. $2012 \mathrm{~m}$. tokių darbuotojų dalis bendrame ne visą darbo laiką dirbančiųjų skaičiuje Lietuvoje sudaré 33,5 proc. (ES-27 27,7 proc.) (žr. 4 lentelę). 
4 lentelè. Ne savo noru ne visą darbo laiką dirbančių darbuotojų dalis nuo bendro ne visą darbo laiką dirbančiųjų skaičiaus Lietuvoje 2000-2012 metais (15-64 metų amžiaus grupèje) (\%)

\begin{tabular}{|l|c|c|c|c|c|c|c|c|c|c|c|c|c|}
\hline & 2000 & 2001 & 2002 & 2003 & 2004 & 2005 & 2006 & 2007 & 2008 & 2009 & 2010 & 2011 & 2012 \\
\hline Iš viso & 50,6 & 64,0 & 59,0 & 59,1 & 53,4 & 49,4 & 35,9 & 27,5 & 22,6 & 31,6 & 39,2 & 37,4 & 33,5 \\
\hline Vyrai & 47,5 & 67,3 & 66,0 & 61,6 & 53,1 & 50,2 & 41,7 & 28,4 & 20,4 & 32,5 & 38,1 & 40,8 & 32,7 \\
\hline Moterys & 52,9 & 61,6 & 53,6 & 57,8 & 53,6 & 48,9 & 32,1 & 26,8 & 23,9 & 30,9 & 40,0 & 35,2 & 33,9 \\
\hline
\end{tabular}

Šaltinis: Eurostat

Ne savo noru ne visą darbo laiką dirbančių darbuotojų vyrų ir moterų dalis buvo panaši ir atitinkamai sudare 32,7 proc. ir 33,9 proc. Svarbu pažymèti ir tai, kad nuo $2001 \mathrm{~m}$. nuosekliai mažejęs šis rodiklis Lietuvoje 2009 m. vèl gerokai išaugo. Tokias tendencijas labiausiai lèmè sumažèję darbo mastai ir sumenkęs darbuotojų poreikis ekonomikos nuosmukio laikotarpiu. Panašios tendencijos formavosi ir kitose ES šalyse. Ekonominès krizès sąlygomis $2009 \mathrm{~m}$. ne savo noru sutrumpintą darbo laiką dirbo: Bulgarijoje - 52,7 proc., Rumunijoje - 51,3 proc., Graikijoje - 49,8 proc., Italijoje - 46,6 proc., Latvijoje 46,1 proc., Ispanijoje - 43,6 proc. dirbančiųjų. $2012 \mathrm{~m}$. tokių darbuotojų dalis padidejjo Bulgarijoje iki 66,5 proc., Graikijoje iki 63 proc., Ispanijoje iki 60,9 proc., Italijoje iki 58,8 proc., o Latvijoje iki 43,5 proc. $2012 \mathrm{~m}$. mažiausiai ne savo noru dirbo sutrumpintą darbo laiką Šveicarijoje (7,6 proc.), Slovenijoje ( 8,6 proc.), Olandijoje $(9,1$ proc.) bei Austrijoje ir Belgijoje (apie 10 proc.). Tačiau svarbu atkreipti dèmesi i tai, jog analizė parodè, kad priverstinis darbas ne visą darbo laiką visiškai nekoreliuoja su vidutinėmis šeimų pajamomis šalyje. Pvz., Bulgarijoje ar Rumunijoje jos yra 3 kartus mažesnès nei Ispanijoje ar Italijoje, nors ne savo noru dirbančiųų sutrumpintą darbo laiką procentas yra panašus (viršija 60 proc.).

Kaip jau minèta, vienas iš darbo ne visą darbo laiką darbuotojams taikymo tikslų siekis derinti šeimos įsipareigojimus ir karjerą. Reikia pažymèti, kad Lietuvos atveju darbo ne visą darbo laiką panaudojimas iš esmès neturi jokių sąsajų su šeimos ir karjeros derinimu. $2010 \mathrm{~m}$. LSD atliko tyrimą, kuriuo buvo siekiama išsiaiškinti darbuotojų karjeros ir šeimos derinimo galimybes. Užimtų gyventojų, auginančių vaiką (-us) iki 8 metų, buvo klausiama, ar jie turi galimybę dirbti sutrumpintas darbo valandas, kad galètų juos prižiūrèti. Tyrimo rezultatai parodè, kad tokią galimybę turèjo tik kas penkta moteris $(20,5$ proc.) ir kas aštuntas vyras (13,1 proc.). Ne viso darbo laiko užimtumui tenka mažas vaidmuo ir siekiant padidinti pažeidžiamų asmenų integraciją ị darbo rinką. Tokią situaciją, visų pirma, lemia žemas darbo užmokestis šalyje. Be to, neretai darbdaviai vengia ịdarbinti specifinėms grupèms priklausančius darbuotojus, kadangi jų atleidimo sąlygos yra sudètingesnès (ilgesnis įspèjimo laikotarpis, didesnès atleidimo išlaidos ir pan.).

Nepaisant visų ne viso darbo laiko teikiamų privalumų, priešpensinio amžiaus asmenys Lietuvoje taip pat nèra suinteresuoti dirbti ne visą darbo dieną, tokiu būdu palengvindami išèjimą iš darbo rinkos. Visų pirma, todẻl, kad mažas darbo užmokestis turi neigiamos įtakos jiems vèliau mokamos pensijos dydžiui (vidutinis senatvès pensijos dydis 
2013 m. kovo mèn. Lietuvoje buvo 819 Lt). Be to, nors DK 146 straipsnio 3 dalyje numatyta, kad darbas ne viso darbo laiko sąlygomis nesukelia jokių apribojimų apskaičiuojant darbo stažą, tačiau pagal Lietuvos Respublikos valstybinio socialinio draudimo ịstatymo1 6 straipsni, socialinio draudimo stažas Lietuvoje nustatomas ne tik pagal draudimo ịmokų mokẻjimo laikotarpị, bet ir pagal įmokų dydị. Pagal minètą įstatymą vieno ménesio socialinio draudimo stažas prilyginamas įmokoms, sumoketoms nuo minimalios mènesinès algos (MMA2) dydžio sumos. Taigi, tais atvejais, kai ịmokos sumokètos nuo mažesnès nei MMA sumos, socialinio draudimo stažas laikomas proporcingai mažesniu [15].

Reikètų pažymèti ir tai, kad ne viso darbo laiko organizavimas neturèjo didelès ịtakos ir moterų užimtumui Lietuvoje. Tam, be anksčiau minètų priežasčių, ịtakos turèjo ir iki $2011 \mathrm{~m}$. Lietuvoje galiojusi vaiko priežiūros atostogų tvarka. Pagal minètą tvarką iki vaikui sukaks dveji metai vienam iš tèvų pirmaisiais vaiko priežiūros metais buvo mokama 100 proc. kompensuojamojo užmokesčio siekianti pašalpa, antraisiais vaiko priežiūros metais - 70 proc. pašalpa. Vaiko priežiūros atostogu išejusiai motinai/tèvui įsidarbinus ir pradejjus gauti pajamų, pašalpa buvo atitinkamai mažinama (mokamas tik pašalpos ir asmens atitinkamą mėnesį turètų draudžiamųjų pajamų skirtumas). Tai neskatino vaiko priežiūros atostogų išèjusių tèvų dirbti, jiems pritaikant lanksčias užimtumo formas. Nuo $2011 \mathrm{~m}$. liepos 1 d. šalyje įsigaliojo Lietuvos Respublikos ligos ir motinystès socialinio draudimo ịstatymo pakeitimo ịstatymas (Žin., 2010, Nr. 86-4533), kuriuo buvo sumažintas mokamos pašalpos dydis, tačiau sudarytos palankesnès sąlygos dirbti norintiems tėvams.

\section{Darbo ne visą darbo laiką sąsajos su skirtingais socialiniais ekonominiais rodikliais Lietuvoje ir ES šalyse}

Siekiant detaliau panagrinèti tarpusavio ryšius tarp ne visą darbo laiką dirbančių gyventojų skaičiaus ir skirtingų socialinių ekonominių rodiklių Lietuvoje ir ES šalyse, buvo atlikta koreliacinė analizè, apskaičiuojant Pirsono koreliacijos koeficientą, leidžiantị įvertinti dviejų kintamujų tarpusavio ryšius. Priklausomybei ịvertinti buvo pasirinkti šie socialiniai ekonominiai rodikliai Lietuvoje ir ES-27:

- bendras užimtujų skaičius;

- BVP, tenkantis vienam gyventojui, išreikštas perkamosios galios standartu (PGS);

- gimstamumo suminis rodiklis;

- bendras apmokestinimo lygis3;

- metinis neto darbo užmokestis, išreikštas PGS4;

- mažas pajamas gaunančių asmenų apmokestinimo lygis.

Statistinè analizè parodè, kad pagal Pirsono koreliacijos koeficientą, ne visą darbo dieną dirbančiųjų skaičius Lietuvoje statistiškai reikšmingai (esant 0,05 reikšmingumo

\footnotetext{
${ }^{1}$ Lietuvos Respublikos valstybinio socialinio draudimo ịstatymas. Žin., 1991, Nr. 17-447.

22013 m. balandžio mèn. MMA dydis neatskaičius mokesčių Lietuvoje buvo 1000 Lt.

${ }^{3}$ Apskaičiuotas 4 asmenų namų ūkiui (2 tèvai ir 2 vaikai), kai abu sutuoktiniai dirba.

${ }^{4}$ Apskaičiuotos pajamos, tenkančios 4 asmenų namų ūkiui (2 tèvai ir 2 vaikai).
} 
lygmeniui) nekoreliuoja nei su vienu pasirinktu faktoriniu kintamuoju, nes p reikšmė yra didesnè už 0,05 .

Šiek tiek skirtingi rezultatai gauti, nagrinejjant sąryšị tarp ne visą darbo laiką dirbančiu gyventojų skaičiaus ir minètų rodiklių ES-27 (jų vidurkių). Pagal Pirsono koreliacijos koeficientą, ne visą darbo dieną dirbančiųjų skaičius ES-27 lygmeniu statistiškai reikšmingai (esant 0,05 reikšmingumo lygmeniui) koreliuoja su BVP vienam gyventojui, išreikštu PGS $(\mathrm{R}=0,964)$, ir su bendru užimtųjų skaičiumi ES-27 $(\mathrm{R}=0,928)$. Tai reiškia, kad, didejjant BVP vienam gyventojui arba bendram užimtųjų skaičiui, dideja ir ne visą darbo laiką dirbančių gyventojų skaičius, ir atvirkščiai.

Galima daryti prielaidą, kad viena pagrindinių tokios situacijos priežasčių yra mažas darbo ne visą darbo laiką ekonominis patrauklumas Lietuvoje. Taip pat skirtumą iš dalies galima paaiškinti tuo, kad Lietuvoje nemaža dalis asmenų, dirbančių ne visą darbo laiką, dirba ne pagrindinejje darbovietèje, todèl bendras užimtumo didejjimas nebūtinai padidina ir dirbančių ne visą darbo laiką asmenų skaičių, kaip kad ES-27 šalių atveju. Siekiant nustatyti tikslesnes minètų skirtumų priežastis, tikslinga atlikti detalesnị darbo ne visą darbo laiką sąsajų su skirtingais socialiniais ekonominiais rodikliais Lietuvoje ir ES šalyse tyrimą.

\section{Išvados}

1. Siekiant efektyviau subalansuoti gamybos ir darbo išteklių poreikius, jau devintame XX a. dešimtmetyje aktyviai pradètos taikyti ịvairios lankstaus užimtumo formos, iš kurių labiausiai paplitusi yra darbas ne visą darbo laiką. Tačiau ši užimtumo forma skirtingose ES šalyse yra paplitusi nevienodai, tarp šalių egzistuoja dideli skirtumai.

2. Literatūros šaltinių analizè parodè, kad darbo ne visą darbo laiką paplitimui šalyje didžiausios įtakos turi šie darbo rinkos instituciniai veiksniai: darbo ne visą darbo laiką reglamentavimas (nustatytas įstatymais ar grindžiamas kolektyviniais susitarimais), skirtingų socialinių išmokų mokèjimo tvarka ir socialinės garantijos, mokesčių sistema, susiklosčiusios darbo rinkos tradicijos šalyje ir mažas vidutinis darbo užmokestis (lyginant su minimaliu gyvenimo lygiu). Neretai prie darbui ne visą darbo laiką įtakos turinčių veiksnių priskiriamas nepakankamas kokybiškų vaiko priežiūros paslaugų prieinamumas, darbo valandų organizavimo ir panaudojimo kultūrų skirtumai bei žemesnio lygio ne viso darbo laiko darbo vietu kokybè. Taip pat darbas ne visą darbo laiką dažnai priklauso ir nuo asmeninio lygio priežasčių: amžiaus, sveikatos būklès, lyties, išsilavinimo, šeiminès padèties ir ịsipareigojimų šeimoje.

3. Darbas ne visą darbo laiką turi teigiamos ịtakos tiek šalies gyventojų gyvenimo kokybei, tiek ir visai šalies ekonomikai - suteikia darbuotojams daugiau lankstumo, leidžia planuoti ir lanksčiau paskirstyti darbo jëgos paklausą, atsižvelgiant ị gamybos poreikius. Lankstūs darbo organizavimo modeliai sudaro galimybes darbuotojams geriau kontroliuoti laiką, derinti šeimos įsipareigojimus ir karjerą, mažina stresą darbe, didina pasitenkinimą darbu. Tačiau darbas ne visą darbo dieną gali turèti ir neigiamo poveikio darbuotojams, 
jie dažniau dirba paprastesnị ir mažiau mokamą darbą lyginant su visą darbo laiką dirbančiais darbuotojais, rečiau dalyvauja mokymuose ir kvalifikacijos tobulinimo kursuose, jiems sudaromos mažesnès karjeros galimybès.

4. Eurostato duomenimis, dirbantieji ne visą darbo laiką Lietuvoje sudaro nedidelę visų dirbančiųjų dalị (2012 m. - 8,8 proc.) lyginant su kitomis ES šalimis (ES-27 19,2 proc.). Tokią situaciją daugiausiai lemia žemas vidutinis darbo užmokestis Lietuvoje bei susiklosčiusios darbo tradicijos šalyje. Kitose ES šalyse dirbančiųjų ne visą darbo laiką dalis lyginant su bendruoju užimtujjų skaičiumi tuo pačiu laikotarpiu svyravo nuo 2,2 proc. Bulgarijoje iki 49,2 proc. Nyderlanduose. Vidutiniškai ES šalyse moterys keturis kartus dažiau dirba ne visą darbo laiką nei vyrai $(2012 \mathrm{~m}$. duomenimis, atitinkamai 32,1 proc. ir 8,4 proc.). Duomenų analizè taip pat parodè, kad gana didelè dalis darbuotojų tiek Lietuvoje, tiek ir kitose ES šalyse ne visą darbo laiką dirba ne savo noru. Lietuvoje tokių darbuotojų dalis $2012 \mathrm{~m}$. sudare 33,5 proc., ES-27 - 27,7 proc.

5. Vertinant darbą ne visą darbo laiką Lietuvoje, reikia pažymèti, kad jis iš esmès neturi didesnès įtakos darbuotojų galimybèms derinti šeimos ir profesinès karjeros ịsipareigojimus. Be to, tokia užimtumo forma neturi didesnès ịtakos ir moterų, jaunimo bei priešpensinio amžiaus asmenų užimtumui.

6. ES šalyse užfiksuota dèsninga priklausomybè tarp dirbančių ne visą darbo laiką asmenų skaičiaus ir bendro užimtujų gyventojų skaičiaus bei BVP, tenkančio vienam gyventojui, rodiklių. Lietuvoje dirbančiujų ne visą darbo laiką rodiklis statistiškai reikšmingai nekoreliuoja nei su vienu iš pasirinktų socialinių ekonominių rodiklių. Kaip pagrindinę to priežastị galima ịvardinti darbo ne visą darbo laiką ekonominị nepatrauklumą, kurị lemia žemas vidutinis darbo užmokestis šalyje.

\section{Literatūra}

1. Bagdanskis, T., Usonis, J. Problems of introduction of flexibility into Lithuanian labour law. Jurisprudence, 2011, 18(2), 595-612.

2. Blaziene, I. Incentives for indefinite employment. Statements and Comments. Peer Review Paper. Vilnius: Institute of Labour and Social Research, 2006. http://www.mutual-learningemployment.net/uploads/ModuleXtender/PeerReviews/68/Lithuania\%20ES_06.pdf [2013-0502].

3. Blaziene, I. Lithuania: Flexible forms of work: ,very atypical contractual arrangements. Dublin: European Foundation for the Improvement of Living and Working Conditions, 2010.

4. Blaziene, I. Working time in the European Union: Lithuania. Dublin: European Foundation for the Improvement of Living and Working Conditions, 2009. http://www.eurofound.europa.eu/ ewco/studies/tn0803046s/lt0803049q.htm [2013-04-05].

5. Blaziene, I., Gruzevskis, B. Anticipating and managing restructuring: Lithuania. National background paper. Turin: ILO International Training Centre, 2009, $77 \mathrm{p}$.

6. Borkowska, S. 2005. Praca a zycie pozazawodowe. Kn. Przyszlosc pracy w XXI wieku. IPiSS, GUS, p. 52-71. 
7. Buddelmeyer, H., Mourre, G., Ward, M. Why do Europeans work part-time? A cross-country panel analysis. No. 872 2008, 51 p. http://www.ecb.int/pub/pdf/scpwps/ecbwp872.pdf [201305-02].

8. Conran, S. The Guide to the Work-Life Balance Sector, 2001/2. www.w-lb.org.uk [2013-04-02].

9. Davulis, T., Petrylaite, D. Tackling the economic crisis: Labour law in Lithuania. Labour Regulation in the 21st Century: In Search of Flexibility and Security, 2012, p. 3-16.

10. Delson, L. When do men work part-time? In O'Reilly, J. and Fagan,C. (Eds) Part-Time Prospects: An International Comparison of Part-Time Work in Europe, North America and the Pacific Rim, Routledge. London, 1998, p. 57-76.

11. Gruzevskis, B., Blaziene, I. Amendments of the Lithuanian Labour Code designed to increase labour market flexibility and to foster social dialogue. European Employment Observatory, 2009. http://www.eu-employment-observatory.net/resources/reports/LithuaniaLabourCodeAmendments.pdf [2013-03-01].

12. Guobaite-Kirsliene, R. The Features of legal regulation part-time work. Social Sciences Studies, 2010, 4(8), 317-338.

13. Lietuvos Respublikos socialinès apsaugos ir darbo ministro ịsakymas „Dèl rekomendacijų darbdaviams ir darbuotojams jų susitarimu taikyti lanksčias darbo organizavimo formas patvirtinimo“. Valstybès žinios, 2003, Nr. 101-4573.

14. Jacukowicz, Z. Nowy swiat pracy. Kn. Przyszlosc pracy w XXI wieku. IPiSS, GUS, 2005, p. 85-98.

15. Macernyte Panomarioviene, I. Flexicurity concept and implementation possibilities in Lithuanian employment policy. Jurisprudence, 2011, 18(3), 1081-1099.

16. Part-time work in Europe. European Company Survey 2009. European Foundation for the improvement of Living and working conditions, 2011. http://www.eurofound.europa.eu/ pubdocs/2010/86/en/3/EF1086EN.pdf [2013-04-15].

17. Working time in the EU. Foundation Findings. European Foundation for the Improvement of Living and Working Conditions, 2012.

18. Žičkienè S., Kovierienè A. Lankstūs darbo organizavimo modeliai: teoriniai ir praktiniai aspektai. Ekonomika ir vadyba: aktualijos ir perspektyvos, 2008, 12(3), 405-419.

\section{Boguslavas Gruževskis, Rasa Zabarauskaitė}

\section{Part-time Employment in Lithuania and Other EU Countries: Trends and Key Issues}

Abstract

Economic globalization and development of information technologies have had a significant impact on the utilisation of labour resources as well as on organization of work in many countries over the past decade. To balance the needs of production and labour resources, in the ninth decade of the $20^{\text {th }}$ century, many countries introduced flexible forms of employment. Part-time employment is the most widely used flexible form of employment in many countries across the world. However, there are large differences existing in EU countries in terms of development of part-time employment, which requires a particular investigation. On the other hand, apart from benefits, part-time employment entails some drawbacks. The article aims at objectively assessing key advantages and disadvantages of part-time employment as well as analysing the dynamics 
of part-time employment in Lithuania and other EU countries. Key factors influencing part-time employment are analysed in the article, while putting a special focus on the regulation of part-time employment in Lithuania and the dynamics of part-time employment in some of the EU countries.

Boguslavas Gruževskis - Lietuvos socialinių tyrimų centro Darbo ir socialinių tyrimų instituto direktorius, profesorius, socialinių mokslų daktaras (HP).

E. paštas: boguslavas.gruzevskis@dsti.lt

Rasa Zabarauskaitè - Lietuvos socialinių tyrimų centro Darbo ir socialinių tyrimų instituto vyresnioji mokslo darbuotoja, socialinių mokslų daktarè.

E. paštas: rasa.zabarauskaite@dsti.lt

Boguslavas Gruževskis, Doctor of Social Sciences (Sociology, 05S), Institute of Labour and Social Research of the Lithuanian Social Research Centre, Director, Professor.

E-mail: boguslavas.gruzevskis@dsti.lt

Rasa Zabarauskaite, Doctor of Social Sciences (Economics, 04S), Institute of Labour and Social Research of the Lithuanian Social Research Centre, Senior Researcher.

E-mail: rasa.zabarauskaite@dsti.lt

Straipsnis ịteiktas redakcijai $2013 \mathrm{~m}$. liepos 18 d.; recenzuotas; parengtas spaudai $2013 \mathrm{~m}$. spalio mèn. 